\title{
Development of Validated HPLC and HPTLC Methods for Simultaneous Determination of Levocetirizine Dihydrochloride and Montelukast Sodium in Bulk Drug and Pharmaceutical Dosage Form
}

\author{
Atul S. Rathore, L. Sathiyanarayanan and K.R. Mahadik*
}

Department of Pharmaceutical Chemistry, Bharati Vidyapeeth University, Poona College of Pharmacy, Erandwane, Pune-411038, Maharashtra, India

\begin{abstract}
Two chromatographic methods have been described for the simultaneous determination of levocetirizine dihydrochloride and Montelukast sodium in tablets. The first method was a high performance thin layer chromatographic (HPTLC) separation followed by densitometric measurements on normal phase silica gel $60 \mathrm{~F}_{254}$. The second method was a high performance liquid chromatographic (HPLC) separation on a BDS Hypersil $\mathrm{C}_{18}$ column using disodium hydrogen phosphate buffer $(0.02 \mathrm{M})$ : Methanol (25: $75, \mathrm{v} / \mathrm{v}) \mathrm{pH}$ adjusted to 7 with ortho-phosphoric acid as the mobile phase. The proposed methods were validated as per ICH guidelines and successfully applied for the determination of investigated drugs in tablets.
\end{abstract}

Keywords: Levocetirizine dihydrochloride; Montelukast sodium; HPLC; HPTLC; Method validation

\section{Introduction}

Levocetirizine (Figure 1a), chemically 2-[2-[4-[(R)-(4-chlorophenyl)phenyl-methyl]piperazin-1-yl]ethoxy]acetic acid, is a third-generation non-sedative antihistamine and used in the form of levocetirizine dihydrochloride for the treatment of allergic rhinitis and chronic idiopathic urticaria. It is an active R-enantiomer of cetirizine, orally active, potent, selective and long acting H1-histamine receptor antagonist with no anticholinergic activity [1-2]. Montelukast (Figure 1b), chemically 2-[1-[[(1R)-1-[3-[2-(7-chloroquinolin-2-yl)ethenyl] phenyl]-3-[2-(2-hydroxypropan-2yl)phenyl]propyl]sulfanylmethyl] cyclopropyl] acetic acid is a selective and orally active leukotriene receptor antagonist that inhibits the cysteinyl leukotriene (CysLT $\left.{ }_{1}\right)$ receptor in the lungs and bronchial tubes. It is used in the form of montelukast sodium for the treatment of asthma and to relieve symptoms of seasonal allergies [3-6]. It has been demonstrated by recent studies that the treatment of allergic rhinitis with concomitant administration of an antileukotriene (Montelukast sodium) and an antihistamine (levocetirizine), shows significantly better symptom relief compared with the modest improvement of rhinitis symptomatically with each of the treatments alone [7-8]. Literature review reveals that some analytical methods have been reported for levocetirizine dihydrochloride [9-12] and montelukast

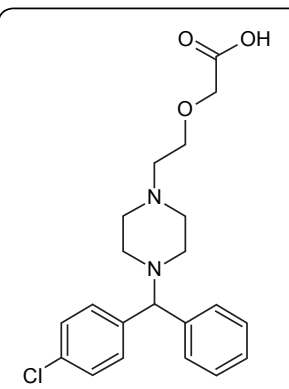

a)

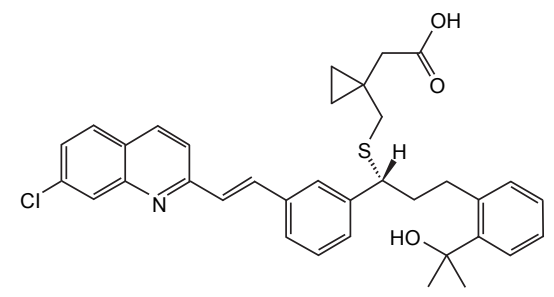

Figure 1: (a) structure of levocetirizine dihydrochloride (b) structure of Montelukast sodium. sodium [13-15] individually as stability indicating and in biological fluids or in combination with other drugs in pharmaceutical dosage forms. Recently HPLC and HPTLC methods has been reported for simultaneous estimation of levocetirizine dihydrochloride and Montelukast sodium in pharmaceutical dosage forms which are either tedious or expensive methods $[16,17]$. The HPLC method uses acetonitrile which is expensive than methanol as the mobile phase whereas HPTLC method uses cholorform as a component of mobile phase which undesirable in the TLC separation. In the present study we have proposed new validated simple HPTLC and reliable LC methods for the simultaneous determination of levocetirizine dihydrochloride and Montelukast sodium in their combined tablet formulation.

\section{Material and Methods}

\section{Chemicals}

Working standards of pharmaceutical grade levocetirizine dihydrochloride $(99.78 \%, \mathrm{w} / \mathrm{w})$ and Montelukast sodium $(99.30 \%$, $\mathrm{w} / \mathrm{w}$ ) were obtained as gift samples from Unichem Laboratories Ltd. Bardez Goa, India and Lupin Ltd. Mulshi, Pune, India respectively. Fixed dose combination Tablets (Montair-LC) containing $5 \mathrm{mg}$ of levocetirizine dihydrochloridedihydrochloride and $10 \mathrm{mg}$ of Montelukast sodium sodium were purchased from a local pharmacy, Pune, India. All chemicals and reagents of analytical grade were purchased from Merck Chemicals, Mumbai, India. High purity

*Corresponding author: K.R. Mahadik, Department of Pharmaceutical Chemistry, Bharati Vidyapeeth University, Poona College of Pharmacy, Erandwane, Pune411038, Maharashtra, India, E-mail: krmahadik@rediffmail.com

Received August 30, 2010; Accepted September 27, 2010 Published September 30, 2010

Citation: Rathore AS, Sathiyanarayanan L, Mahadik KR (2010) Development of Validated HPLC and HPTLC Methods for Simultaneous Determination of Levocetirizine Dihydrochloride and Montelukast Sodium in Bulk Drug and Pharmaceutical Dosage Form. Pharm Anal Acta 1:106. doi:10.4172/2153 2435.1000106

Copyright: (c) 2010 Rathore AS, et al. This is an open-access article distributed under the terms of the Creative Commons Attribution License, which permits unrestricted use, distribution, and reproduction in any medium, provided the original author and source are credited. 
Citation: Rathore AS, Sathiyanarayanan L, Mahadik KR (2010) Development of Validated HPLC and HPTLC Methods for Simultaneous Determination of Levocetirizine Dihydrochloride and Montelukast Sodium in Bulk Drug and Pharmaceutical Dosage Form. Pharm Anal Acta 1:106. doi:10.4172/2153-2435.1000106

Page 2 of 6

deionized water was obtained from Millipore, Milli-Q (Bedford, MA, USA) water purification system.

\section{Instrumentation and chromatographic conditions}

For HPTLC, the samples were spotted in the form of bands of 6 $\mathrm{mm}$ width with a Camag 100 microlitre sample syringe (Hamilton, Bonaduz, Switzerland) on silica gel precoated aluminum plate $60 \mathrm{~F}_{254}$, [ $(20 \times 10 \mathrm{~cm})$ with $250 \mu \mathrm{m}$ thickness; E. Merck, Darmstadt, Germany, supplied by Anchrom Techno, Mumbai] using a Camag Linomat IV applicator (Switzerland). The plates were prewashed with methanol and activated at $110^{\circ} \mathrm{C}$ for $5 \mathrm{~min}$ prior to chromatography. A constant application rate of $0.1 \mu \mathrm{Ls}^{-1}$ was used and the space between two bands was $6 \mathrm{~mm}$. The slit dimension was kept at $5 \mathrm{~mm} \times 0.45$ $\mathrm{mm}$ and the scanning speed was $10 \mathrm{~mm} \mathrm{~s}^{-1}$. The mobile phase was consisted of toluene: ethyl acetate: methanol: ammonia (2.5: 7: 2.5: 1, $\mathrm{v} / \mathrm{v} / \mathrm{v} / \mathrm{v}$ ) and $15 \mathrm{~mL}$ of the mobile phase was used for chromatography. Linear ascending development was carried out in $20 \mathrm{~cm} \times 10 \mathrm{~cm}$ twin trough glass chamber (Camag, Muttenz, Switzerland) saturated with the mobile phase. The optimized chamber saturation time for mobile phase was $30 \mathrm{~min}$ at room temperature $\left(25^{\circ} \mathrm{C} \pm 2\right)$. The length of chromatogram run was $8 \mathrm{~cm}$. Densitometric scanning was performed using a Camag TLC scanner III in the reflectance-absorbance mode and operated by CATS software (V 3.15, Camag). The source of radiation used was a deuterium lamp emitting a continuous UV spectrum between 190 and $400 \mathrm{~nm}$. Concentrations of the compound chromatographed were determined from the intensity of the diffused light. Evaluation was by peak areas with linear regression. The HPLC system (Jasco corporation, Tokyo, Japan) consisted of a Pump (model Jasco PU- 2080 Plus) along with manual injector sampler programmed at $20 \mu \mathrm{l}$ capacity per injection was used. The detector consisted of UV/ VIS (model Jasco UV 2075). LC separations were performed on a BDS Hypersil $C_{18}$ analytical column Dim. $(\mathrm{mm}) 250 \times 4.6$, Particle Sz. ( $\mu$ ) 5 (Thermo Scientific, Waltham, USA). Data was integrated using Jasco Borwin version 1.5, LC-Net II/ADC system. The mobile phase was consisted of a mixture of Sodium dihydrogen phosphate buffer $(0.02$ $\mathrm{M})$ : Methanol (25: 75, v/v) pH adjusted to 7 with ortho-phosphoric acid. The mobile phase was degassed and filtered by passing through a $0.45 \mu \mathrm{m}$ pore size membrane filter (Millipore, Milford, MA, USA) prior to use. The flow rate was $1 \mathrm{~mL} \mathrm{~min}^{-1}$. All determinations were performed at ambient temperature with a detection wavelength of $231 \mathrm{~nm}$.

\section{Preparation of standard stock and working solutions}

Mixed standard stock solution containing $1.00 \mathrm{mg} \mathrm{mL}^{-1}$ of levocetirizine dihydrochloride and $2.00 \mathrm{mg} \mathrm{mL}^{-1}$ of Montelukast sodium was prepared in methanol. For HPTLC, the working standard solution of levocetirizine dihydrochloride and Montelukast sodium was prepared at concentration of $500 \mathrm{ng} \mu \mathrm{L}^{-1}$ and $1000 \mathrm{ng} \mu \mathrm{L}^{-1}$ respectively, by diluting the standard stock solution in methanol. For HPLC, working standard solutions were prepared by diluting the above standard stock solution in mobile phase to reach a concentration range of $1-10 \mu \mathrm{g} \mathrm{mL}^{-1}$ for levocetirizine dihydrochloride and $2-20$ $\mu \mathrm{g} \mathrm{mL} \mathrm{m}^{-1}$ for Montelukast sodium. The stock solution was stored at $2-8^{\circ} \mathrm{C}$ protected from light.

\section{Selection of analytical wavelength}

Stock solutions of drugs were prepared in methanol separately. UV spectrum of $10 \mu \mathrm{g} \mathrm{mL}{ }^{-1}$ of each individual drug was taken. Levocetirizine dihydrochloride and montelukast sodium showed maximum absorbance at $230 \mathrm{~nm}$ and $344 \mathrm{~nm}$, respectively. Isobestic point was found at $231 \mathrm{~nm}$ and was selected as the detection wavelength (Figure 2a). Further, in situ HPTLC spectral overlain of levocetirizine dihydrochloride and montelukast sodium was taken.
Isobestic point at $231 \mathrm{~nm}$ was confirmed and was selected as scanning wavelength (Figure $2 \mathrm{~b}$ ).

\section{Optimization of HPTLC and HPLC method}

The HPTLC and HPLC procedures were optimized with a view to develop a simultaneous assay method for levocetirizine dihydrochloride and montelukast sodium. For HPTLC, the mixed standard stock solution containing $1.00 \mathrm{mg} \mathrm{mL}^{-1}$ of levocetirizine dihydrochloride and $2.00 \mathrm{mg} \mathrm{mL}$ of montelukast sodium was spotted onto HPTLC plates and run in different solvent systems. Several mobile phases were tried on trial and error basis and finally a mobile phase consisted of toluene:ethyl acetate:methanol:ammonia ( 2.5: 7: 2.5: 1, v/v/v/v) was selected. In order to reduce the neckless effect the TLC chamber was saturated for $30 \mathrm{~min}$ using saturation pads. The mobile phase was run up to a distance of $8 \mathrm{~cm}$; which takes approximately $25 \mathrm{~min}$. for complete development of the TLC plate.

For HPLC, The mixed standard stock solution was diluted in mobile phase to a concentration containing $10 \mu \mathrm{g} \mathrm{mL}$ of levocetirizine dihydrochloride and $20 \mu \mathrm{g} \mathrm{mL}^{-1}$ of Montelukast sodium. Then, the stock solution is injected into the BDS Hypersil $\mathrm{C}_{18}$ analytical column. Different ratios of Disodium hydrogen phosphate buffer $(0.02 \mathrm{M})$ and Methanol at different $\mathrm{pH}$ were tried. The optimum mobile phase was found to be Disodium hydrogen phosphate buffer $(0.02 \mathrm{M})$ : Methanol (25: $75 \mathrm{v} / \mathrm{v}), \mathrm{pH}$ adjusted to 7 with ortho-phosphoric acid. The
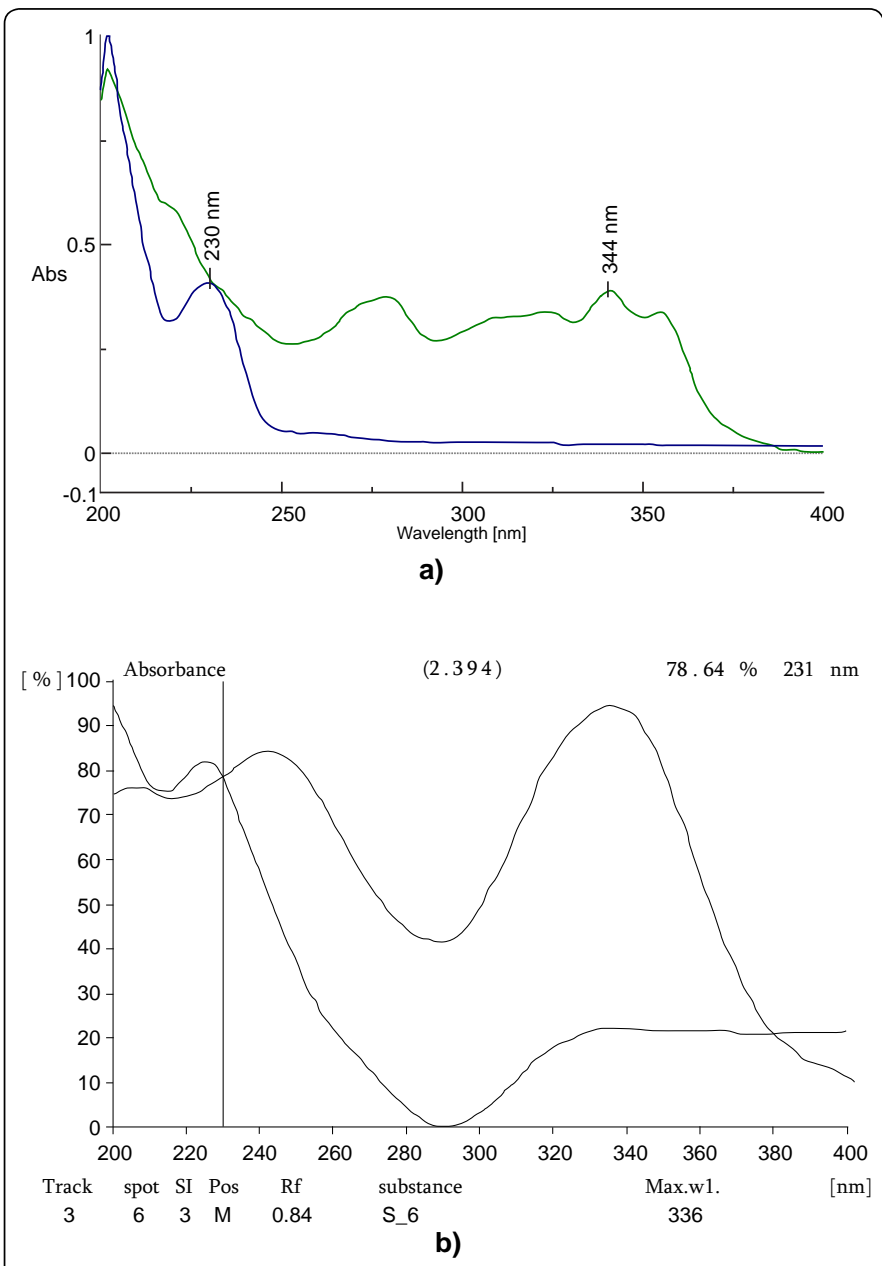

Figure 2: (a) UV spectrum overlay of levocetirizine dihydrochlorideand Montelukast sodium (b) In situ HPTLC spectral overlain of levocetirizine dihydrochlorideand Montelukast sodium. 
Citation: Rathore AS, Sathiyanarayanan L, Mahadik KR (2010) Development of Validated HPLC and HPTLC Methods for Simultaneous Determination of Levocetirizine Dihydrochloride and Montelukast Sodium in Bulk Drug and Pharmaceutical Dosage Form. Pharm Anal Acta 1:106. doi:10.4172/2153-2435.1000106

separation was carried out at ambient temperature with a flow rate of $1.0 \mathrm{~mL} \mathrm{~min}{ }^{-1}$. The retention times for levocetirizine dihydrochloride and montelukast sodium were found to be $3.558 \pm 0.03$ and 7.450 $\pm 0.04 \mathrm{~min}$, respectively. Acceptable retention time $\left(t_{R}\right)$, plates, asymmetry and good resolution for levocetirizine dihydrochloride and Montelukast sodium were obtained.

\section{Validation of HPTLC and HPLC method}

The optimized HPTLC \& HPLC method was validated with respect to the following Parameters. The validation was performed as per the ICH guidelines $[18,19]$.

Linearity: For HPTLC, 1 to $5 \mu \mathrm{L}$ volumes of the working standard stock solution were spotted in triplicate on HPTLC plate to obtain a final concentration range of 500-2500 $\mathrm{ng} \mathrm{spot}^{-1}$ for levocetirizine dihydrochloride and 1000-5000 $\mathrm{ng} \mathrm{spot}^{-1}$ for montelukast sodium. The plate was then developed using the previously described mobile phase. For HPLC, $20-\mu \mathrm{L}$ of working standard solution was injected into the HPLC system six times for each concentration and chromatographed under the above mentioned conditions. Linear calibration curves were generated using least-squares linearregression analysis by plotting the peak area against concentration of the drug. The limit of detection (LOD) and limit of quantification (LOQ) were determined by diluting known concentrations of standard stock solution until the average responses were approximately three (For LOD) or ten times (for LOQ) the responses of the blank.

Precision: The precision of the method was analyzed by repeatability and intermediate precision studies. Repeatability studies were performed by analysis of three different concentrations of 500 , $1500,2500 \mathrm{ng} \mathrm{spot}^{-1}$ and 1000, 3000, $5000 \mathrm{ng} \mathrm{spot}^{-1}$ for levocetirizine dihydrochloride and Montelukast sodium, respectively by HPTLC and $1,4,10 \mu \mathrm{g} \mathrm{mL}^{-1}$ and 2, 8, $20 \mu \mathrm{g} \mathrm{mL}^{-1}$ for levocetirizine dihydrochloride and Montelukast sodium, respectively by HPLC. Method repeatability was achieved from RSD\% values obtained by repeating the assay six times on the same day for intra-day precision. The intermediate (interday) precision of the method was checked by performing same procedure on different days under the same experimental conditions.

Robustness: The robustness was studied by evaluating the effect of small but deliberate variations in the chromatographic conditions. For HPTLC method, following the introduction of small changes in the mobile phase composition ( $\pm 0.1 \mathrm{~mL}$ for ammonia), the effect on the results was examined. Mobile phases having different proportions of components, e.g. toluene: ethyl acetate: methanol: ammonia (2.6: 7: 2.5: 1, v/v/v/v), (2.4: 7: 2.5: 1, v/v/v/v), (2.5: 7: 2.6: 1, v/v/v/v), (2.5: 7: 2.4: $1, \mathrm{v} / \mathrm{v} / \mathrm{v} / \mathrm{v}$ ) etc., were tried and chromatograms were run. The amount of mobile phase was varied over the range of $\pm 5 \%$. The time from spotting to chromatography and from chromatography to scanning was varied by $10 \mathrm{~min}$ and analysed. The robustness of the method was determined at three different concentration levels of 500,1500, $2500 \mathrm{ng}$ spot $^{-1}$ for levocetirizine dihydrochloride and 1000, 3000, $5000 \mathrm{ng} \mathrm{spot}^{-1}$ for montelukast sodium. For HPLC, robustness of the method was studied by deliberately varying parameters like flow rate $\left( \pm 0.1 \mathrm{~mL} \mathrm{~min}^{-1}\right)$ and mobile phase composition $( \pm 1 \mathrm{~mL})$.

Specificity: The ability of an analytical method to unequivocally assess the analyte in the presence of other components (impurities, degradents and excipients) can be demonstrated by evaluating specificity. The specificity of the HPTLC method was determined by analyzing standard drug and test samples. The spot for levocetirizine dihydrochloride and montelukast sodium in the samples was confirmed by comparing the $\mathrm{R}_{\mathrm{F}}$ and spectrum of the spot to that of a standard. The peak purity of levocetirizine dihydrochloride and montelukast sodium was determined by comparing the spectrum at three different regions of the spot i.e. peak start (S), peak apex $(\mathrm{M})$ and peak end (E). For HPLC, The specificity of the method was determined by injecting excipient solution having the same concentration as that of the tablet solution.

Accuracy: Accuracy of the two proposed methods was carried out by applying the methods to drug sample (Levocetirizine dihydrochloride and Montelukast sodium combination tablets) to which known amount of levocetirizine dihydrochloride and montelukast sodium standard powder corresponding to 50, 100 and $150 \%$ of label claim had been added (standard addition method). The absolute recovery was calculated by comparing the peak areas obtained from standard solution of levocetirizine dihydrochloride and montelukast sodium with the peak areas of samples of different concentration.

Analysis of marketed formulation (Assay): Ten tablets of Montair - LC (labeled to contain $5 \mathrm{mg}$ levocetirizine dihydrochloride and 10 mg montelukast sodium, Cipla Ltd.) were weighed and powdered. An accurate weight of the powder equivalent to $5 \mathrm{mg}$ of levocetirizine dihydrochloride and $10 \mathrm{mg}$ of Montelukast sodium was transferred into a $25 \mathrm{~mL}$ volumetric flask containing $15 \mathrm{~mL}$ methanol, sonicated for $30 \mathrm{~min}$ and diluted up to $25 \mathrm{~mL}$ with methanol. This solution was filtered through a $0.45 \mu \mathrm{m}$ membrane filter. For HPTLC, concentration achieved after the above dilution was $200 \mathrm{ng} \mu \mathrm{L}^{-1}$ of levocetirizine dihydrochloride and $400 \mathrm{ng} \mu \mathrm{L}^{-1}$ of montelukast sodium. $4 \mu \mathrm{L}$ volume was spotted for six times to achieve a final concentration of 800 ng spot ${ }^{-1}$ and 1600 ng spot $^{-1}$ for levocetirizine dihydrochloride and montelukast sodium, respectively. For HPLC, Suitable dilutions were made using mobile phase to prepare final tablet solution containing $10 \mu \mathrm{g} \mathrm{mL} \mathrm{m}^{-1}$ for levocetirizine dihydrochloride and $20 \mu \mathrm{g} \mathrm{mL}{ }^{-1}$ for montelukast sodium. Tablet solutions thus prepared were filtered then analyzed as mentioned under the construction of calibration graphs in the above section. The analysis was repeated for six times.

\section{Results}

\section{Optimization of chromatographic conditions}

The experimental conditions for HPTLC such as wavelength of detection and mobile phase composition were optimized to provide accurate, precise and reproducible results. A scanning wavelength of $231 \mathrm{~nm}$ obtained as a common wavelength concluded from UV spectrum overlay and in situ HPTLC spectral overlay was used. Initially, toluene, acetone and methanol were tried in different ratio. Formic acid was then added to improve the peak shape. But

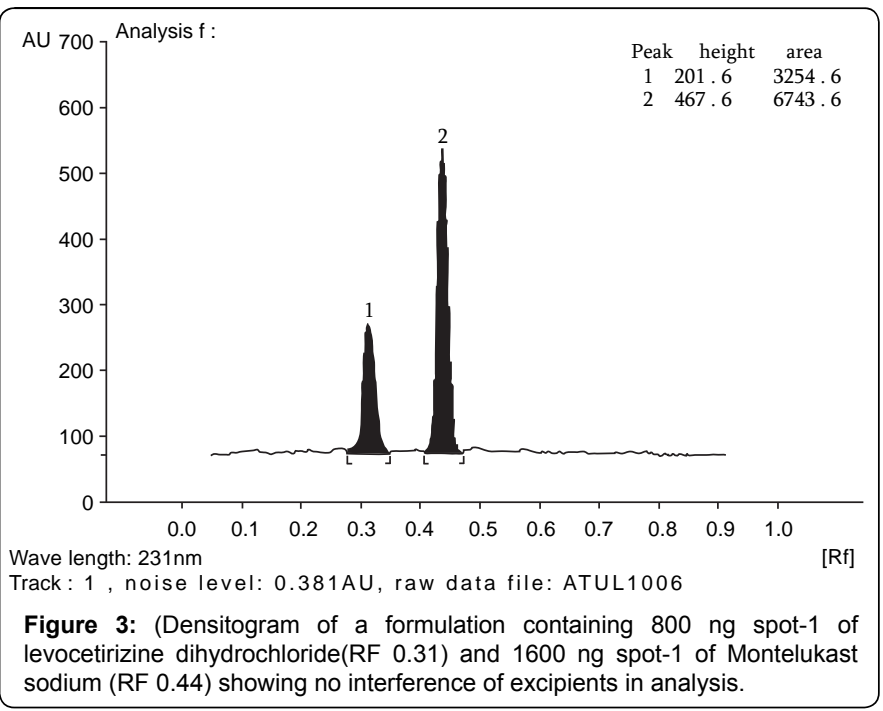


Citation: Rathore AS, Sathiyanarayanan L, Mahadik KR (2010) Development of Validated HPLC and HPTLC Methods for Simultaneous Determination of Levocetirizine Dihydrochloride and Montelukast Sodium in Bulk Drug and Pharmaceutical Dosage Form. Pharm Anal Acta 1:106. doi:10.4172/2153-2435.1000106

Page 4 of 6

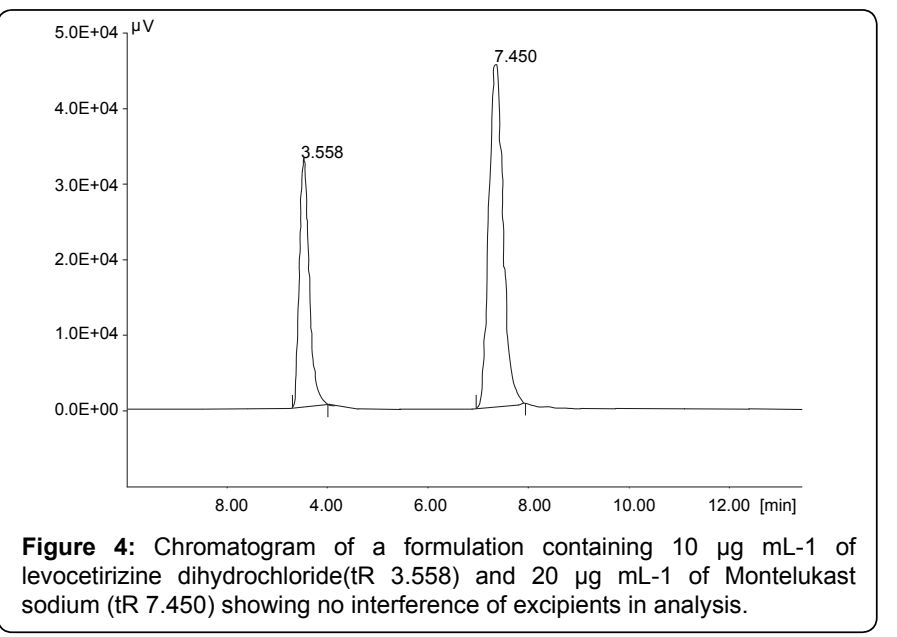

resolution achieved was not satisfactory. Finally, toluene, ethyl acetate, methanol and ammonia were tried in different ratio. The optimum mobile phase was found to be consisted of toluene: ethyl acetate: methanol: ammonia (2.5: 7: 2.5: $1, \mathrm{v} / \mathrm{v} / \mathrm{v} / \mathrm{v})$. The drugs were satisfactorily resolved with $R_{F}$ values at $0.31 \pm 0.01$ and $0.44 \pm$ 0.01 for levocetirizine dihydrochloride and montelukast sodium, respectively. A good resolution and sharp peaks were obtained with minimum tailing with the proposed mobile phase (Figure 3).

To optimize the HPLC assay conditions, different ratios of Sodium dihydrogen phosphate buffer $(0.02 \mathrm{M})$ and methanol at different $\mathrm{pH}$ were tried. The optimum mobile phase was found to be consisted of sodium dihydrogen phosphate buffer $(0.02 \mathrm{M})$ and methanol $(25$ $75, \mathrm{v} / \mathrm{v}), \mathrm{pH}$ adjusted to 7 with ortho-phosphoric acid. The separation was carried out at ambient temperature with a flow rate of $1.0 \mathrm{~mL}$ $\mathrm{min}^{-1}$. The retention times for levocetirizine dihydrochloride and montelukast sodium were found to be $3.558 \pm 0.03$ and $7.450 \pm$

(a) HPTCL

\begin{tabular}{|l|l|l|}
\hline Parameters & Levocetirizine & Montelukast \\
\hline Linearity range & $500-2500 \mathrm{ng} \mathrm{spot}^{-1}$ & $1000-5000 \mathrm{ng} \mathrm{spot}^{-1}$ \\
\hline $\mathrm{r}^{2} \pm$ S.D. & $0.9981 \pm 0.0007$ & $0.9982 \pm 0.002$ \\
\hline Slope \pm S.D. & $2.768 \pm 0.005$ & $1.756 \pm 0.001$ \\
\hline Intercept \pm S.D $^{-D}$ & $961 \pm 1.92$ & $3602 \pm 3.40$ \\
\hline Confidence limit of slope $^{\mathrm{a}}$ & $2.547-2.990$ & $1.618-1.893$ \\
\hline Confidence limit of intercept & \\
\hline Sy.$X$ & $594.2-1328$ & $3146-4057$ \\
\hline
\end{tabular}

(b) By HPLC

\begin{tabular}{|l|l|l|}
\hline Parameters & Levocetirizine & Montelukast \\
\hline Linearity range & $1-10 \mu \mathrm{mL}^{-1}$ & $2-20 \mu \mathrm{mL}^{-1}$ \\
\hline $\mathrm{r}^{2} \pm$ S.D. & $0.9987 \pm 0.00$ & $0.998 \pm 0.01$ \\
\hline Slope \pm S.D. & $40810 \pm 19.44$ & $56040 \pm 21.61$ \\
\hline Intercept \pm S.D & $-4930 \pm 8.04$ & $15460 \pm 6.36$ \\
\hline Intercept \pm S.D & $960.4 \pm 1.92$ & $3601 \pm 3.40$ \\
\hline Confidence limit of slope $^{a}$ & $39120-42510$ & $1.618-1.893$ \\
\hline Confidence limit of intercept ${ }^{a}$ & $-14250-4389$ & $3146-4057$ \\
\hline Sy.$X$ & 5126 & 136.5 \\
\hline
\end{tabular}

${ }^{*} p<0.0001$ - Slope significantly different from zero

a95\% confidence limit.

Sy.X-Standard deviation of residuals from line.

Table 1: Linear regression data for calibration curves.

(a) By HPTCL

\begin{tabular}{|c|c|c|c|c|c|}
\hline \multirow{2}{*}{ Drugs } & \multirow{2}{*}{$\begin{array}{l}\text { Conc. } \\
\left.\text { (ng spot }^{-1}\right)\end{array}$} & \multicolumn{2}{|l|}{$\begin{array}{l}\text { Repeatability } \\
(n=6)\end{array}$} & \multicolumn{2}{|c|}{$\begin{array}{l}\text { Intermediate precision } \\
(n=6)\end{array}$} \\
\hline & & Found conc. \pm SD & RSD (\%) & Found conc. \pm SD & RSD (\%) \\
\hline \multirow{3}{*}{ Levocetirizine } & 500 & $504.07 \pm 2.12$ & 0.42 & $499.95 \pm 0.99$ & 0.20 \\
\hline & 1500 & $1497.51 \pm 27.10$ & 1.81 & $1505.03 \pm 27.84$ & 1.85 \\
\hline & 2500 & $2509.37 \pm 37.39$ & 1.49 & $2501.53 \pm 33.27$ & 1.33 \\
\hline \multirow{3}{*}{ Montelukast sodium } & 1000 & $998.50 \pm 9.19$ & 0.92 & $1009.04 \pm 1.92$ & 0.19 \\
\hline & 3000 & $3035.91 \pm 6.07$ & 0.20 & $2989.31 \pm 12.26$ & 0.41 \\
\hline & 5000 & $4955.98 \pm 60.96$ & 1.23 & $4911.08 \pm 44.20$ & $\mid 0.90$ \\
\hline
\end{tabular}

(b) By HPCL

\begin{tabular}{|c|c|c|c|c|c|}
\hline \multirow[t]{2}{*}{ Drugs } & \multirow{2}{*}{$\begin{array}{l}\text { Conc. } \\
\left(\mu g \mathrm{~mL}^{-1}\right)\end{array}$} & \multicolumn{2}{|l|}{$\begin{array}{l}\text { Repeatability } \\
(n=6)\end{array}$} & \multicolumn{2}{|c|}{$\begin{array}{l}\text { Intermediate precision } \\
(n=6)\end{array}$} \\
\hline & & Found conc. \pm SD & RSD (\%) & Found conc. \pm SD & RSD (\%) \\
\hline \multirow{3}{*}{ Levocetirizine } & 1 & $0.98 \pm 0.002$ & 0.20 & $1.008 \pm 0.000$ & 0.06 \\
\hline & 4 & $4.05 \pm 0.014$ & 0.34 & $4.142 \pm 0.012$ & 0.28 \\
\hline & 10 & $9.97 \pm 0.007$ & 0.07 & $10.280 \pm 0.005$ & 0.04 \\
\hline \multirow{3}{*}{ Montelukast sodium } & 2 & $1.98 \pm 0.002$ & 0.10 & $1.960 \pm 0.003$ & 0.15 \\
\hline & 8 & $8.82 \pm 0.050$ & 0.06 & $8.180 \pm 0.006$ & 0.07 \\
\hline & 20 & $20.860 \pm 0.020$ & 0.10 & $19.910 \pm 0.008$ & 0.04 \\
\hline
\end{tabular}

Table 2: Precision studies 
Citation: Rathore AS, Sathiyanarayanan L, Mahadik KR (2010) Development of Validated HPLC and HPTLC Methods for Simultaneous Determination of Levocetirizine Dihydrochloride and Montelukast Sodium in Bulk Drug and Pharmaceutical Dosage Form. Pharm Anal Acta 1:106. doi:10.4172/2153-2435.1000106

Page 5 of 6

(a) By HPTLC

\begin{tabular}{|c|c|c|c|c|}
\hline \multirow{2}{*}{ Parameters } & \multicolumn{2}{|c|}{ SD of peak area* } & \multicolumn{2}{|c|}{$\%$ RSD } \\
\hline & LEVO. & MONT. & LEVO. & MONT. \\
\hline Mobile phase composition ( $\pm 0.1 \mathrm{ml}$ of ammonia) & 2.78 & 3.12 & 0.75 & 1.12 \\
\hline Amount of mobile phase $( \pm 5 \%)$ & 1.54 & 2.36 & 0.17 & 0.32 \\
\hline Time from spotting to chromatography (10 $\mathrm{min}$ ) & 2.53 & 2.61 & 0.42 & 0.54 \\
\hline Time from chromatography to scanning (10 $\mathrm{min}$ ) & 1.74 & 2.42 & 0.14 & 0.33 \\
\hline
\end{tabular}

(b) By HPTLC

\begin{tabular}{|c|c|c|c|c|c|}
\hline \multirow{2}{*}{ Factor } & \multirow{2}{*}{ Level } & \multicolumn{2}{|c|}{ Retention time } & \multicolumn{2}{|l|}{ Asymmetry } \\
\hline & & LEVO. & MONT. & LEVO. & MONT. \\
\hline \multicolumn{6}{|l|}{ A: Flow Rate $\left(\mathrm{mL} \mathrm{min}^{-1}\right)$} \\
\hline 0.9 & -1 & 3.643 & 7.49 & 1.24 & 1.06 \\
\hline 1.0 & 0 & 3.558 & 7.45 & 1.23 & 1.03 \\
\hline 1.1 & +1 & 3.462 & 7.41 & 1.19 & 1.04 \\
\hline Mean \pm S.D $(n=3)$ & & $3.56 \pm 0.095$ & $7.45 \pm 0.040$ & $1.21 \pm 0.032$ & $1.04 \pm 0.036$ \\
\hline \multicolumn{6}{|c|}{ B: \% of methanol in the mobile phase (v/v) } \\
\hline 24 & -1 & 3.629 & 7.59 & 1.23 & 1.06 \\
\hline 25 & 0 & 3.558 & 7.45 & 1.13 & 1.03 \\
\hline 26 & +1 & 3.487 & 7.31 & 1.17 & 1.04 \\
\hline Mean \pm S.D $(n=3)$ & & $3.558 \pm 0.071$ & $7.55 \pm 0.14$ & $1.17 \pm 0.05$ & $1.04 \pm 0.02$ \\
\hline
\end{tabular}

Table 3. Robustness studies.

(a) By HPTLC

\begin{tabular}{|c|c|c|c|c|c|c|c|}
\hline \multirow{2}{*}{ Drugs } & \multirow{2}{*}{$\begin{array}{l}\text { Label claim } \\
\mathrm{mg} \mathrm{tab}^{-1}\end{array}$} & \multirow{2}{*}{$\begin{array}{l}\text { Amount added in } \mathrm{mg} \\
(\%)\end{array}$} & \multirow{2}{*}{$\begin{array}{l}\text { Total amount } \\
\text { (mg) }\end{array}$} & \multirow{2}{*}{$\begin{array}{l}\text { Actual conc. } \\
\text { taken }\left(\text { ng spot }^{-1}\right)\end{array}$} & \multicolumn{3}{|l|}{ For HPTLC $(n=6)$} \\
\hline & & & & & calculated conc. \pm SD & RSD (\%) & Recovery (\%) \\
\hline \multirow{3}{*}{ Levocetirizine } & \multirow{3}{*}{5} & 2.5 & 7.5 & 600 & $605.61 \pm 3.15$ & 0.52 & 101.87 \\
\hline & & 5 & 10 & 800 & $799.0 \pm 10.47$ & 1.31 & 99.75 \\
\hline & & 7.5 & 12.5 & 1000 & $998.6 \pm 9.19$ & 0.92 & 99.72 \\
\hline \multirow{3}{*}{ Montelukast sodium } & \multirow{3}{*}{10} & 5 & 15 & 1200 & $1212.0 \pm 7.15$ & 0.59 & 102.00 \\
\hline & & 10 & 20 & 1600 & $1604.0 \pm 6.73$ & 0.42 & 100.55 \\
\hline & & 15 & 25 & 2000 & $2001.9 \pm 23.22$ & 1.16 & 100.19 \\
\hline
\end{tabular}

(b) By HPLC

\begin{tabular}{|c|c|c|c|c|c|c|c|}
\hline \multirow{2}{*}{ Drugs } & \multirow{2}{*}{\begin{tabular}{|l} 
Label \\
claim \\
mg tab-1 $^{-1}$
\end{tabular}} & \multirow{2}{*}{$\begin{array}{l}\text { Amount added } \\
\text { in } \mathrm{mg} \\
(\%)\end{array}$} & \multirow{2}{*}{$\begin{array}{l}\begin{array}{l}\text { Total } \\
\text { amount } \\
\text { (mg) }\end{array} \\
\end{array}$} & \multirow{2}{*}{ Actual conc. Taken $\left(\mu \mathrm{g} \mathrm{mL}^{-1}\right)$} & \multicolumn{3}{|l|}{ For HPLC $(n=6)$} \\
\hline & & & & & calculated conc. \pm SD & RSD (\%) & Recovery (\%) \\
\hline \multirow{3}{*}{\begin{tabular}{|l} 
Levo \\
cetirizine
\end{tabular}} & \multirow{3}{*}{5} & $2.5(50 \%)$ & 7.5 & 3 & $3.028 \pm 0.03$ & 0.98 & 100.94 \\
\hline & & $5(100 \%)$ & 10 & 4 & $4.048 \pm 0.03$ & 0.79 & 101.20 \\
\hline & & $7.5(150 \%)$ & 12.5 & 5 & $5.006 \pm 0.02$ & 0.39 & 100.12 \\
\hline \multirow{3}{*}{$\begin{array}{l}\text { Montelukast } \\
\text { sodium }\end{array}$} & \multirow{3}{*}{10} & $5(50 \%)$ & 15 & 6 & $6.16 \pm 0.03$ & 0.48 & 102.66 \\
\hline & & $10(100 \%)$ & 20 & 8 & $8.092 \pm 0.06$ & 0.74 & 101.16 \\
\hline & & $15(150 \%)$ & 25 & 10 & $10.04 \pm 0.02$ & 0.19 & 100.40 \\
\hline
\end{tabular}

Table 4: Accuracy studies.

$0.04 \mathrm{~min}$, respectively (Figure 4). Acceptable retention time $\left(t_{R}\right)$, theoretical plates, asymmetry and good resolution for levocetirizine dihydrochlorideand montelukast sodium were obtained.

\section{Method validation}

Linearity: Linear relationships were observed by plotting drug concentrations against peak areas for each compound, for both chromatographic methods. For HPTLC, levocetirizine dihydrochloride and montelukast sodium showed linear response in the concentration range of 500-2500 ng spot ${ }^{-1}$ and 1000-5000 $\mathrm{ng} \mathrm{spot}^{-1}$, respectively. The corresponding linear regression equation was $\mathrm{y}=2.768 \mathrm{x}+$ 961 and $y=1.756 x+3602$ with square of correlation coefficient $\left(\mathrm{R}^{2}\right)$ of 0.9981 and 0.9982 for levocetirizine dihydrochloride and montelukast sodium respectively. Similarly for HPLC, levocetirizine dihydrochloride and montelukast sodium showed linear response in the range of $1-10 \mu \mathrm{g} \mathrm{mL}^{-1}$ and $2-20 \mu \mathrm{g} \mathrm{mL}^{-1}$, respectively. The corresponding linear regression equation was $\mathrm{y}=40810 \mathrm{x}-4930$ and $y=56040 x-15460$ with square of correlation coefficient $\left(R^{2}\right)$ of
0.9987 and 0.9980 for levocetirizine dihydrochloride and montelukast sodium, respectively. An excellent correlation existed between the peak areas and concentration of levocetirizine dihydrochloride and Montelukast sodium (Table 1). The signal: noise ratios of 3:1 and 10:1 were considered as LOD and LOQ respectively. In HPTLC method, the limit of detection (LOD) and the limit of quantitation (LOQ) were found to be $90 \mathrm{ng}$ spot $^{-1}$ and $200 \mathrm{ng}$ spot $^{-1}$ for Levocericine dihydrochloride and $50 \mathrm{ng} \mathrm{spot}^{-1}$ and $110 \mathrm{ng} \mathrm{spot}^{-1}$ for montelukast sodium respectively. In HPLC method, the limit of detection (LOD) and the limit of quantitation (LOQ) were found to be $0.5 \mu \mathrm{g} \mathrm{mL}^{-1}$ and $0.8 \mu \mathrm{g} \mathrm{mL}^{-1}$ for Levocetricine dihydrochloride and $0.2 \mu \mathrm{g} \mathrm{mL}^{-1}$ and 0.6 $\mu \mathrm{g} \mathrm{mL}{ }^{-1}$ for montelukast sodium respectively.

Precision: The results of the repeatability and intermediate precision experiments are shown in Table 2 . The developed methods were found to be precise as the RSD values for repeatability and intermediate precision studies were $<2 \%$, respectively as recommended by ICH guidelines. 
Citation: Rathore AS, Sathiyanarayanan L, Mahadik KR (2010) Development of Validated HPLC and HPTLC Methods for Simultaneous Determination of Levocetirizine Dihydrochloride and Montelukast Sodium in Bulk Drug and Pharmaceutical Dosage Form. Pharm Anal Acta 1:106. doi:10.4172/2153-2435.1000106

Page 6 of 6

(a) By HPTLC

\begin{tabular}{|c|c|c|c|}
\hline \multirow[b]{2}{*}{ Drugs } & \multirow{2}{*}{$\begin{array}{l}\text { Label claim } \\
\text { mg tablet }^{-1}\end{array}$} & \multicolumn{2}{|c|}{ For HPTLC $(n=6)$} \\
\hline & & $\begin{array}{l}\text { Drug content } \\
(\%) \pm \text { SD }\end{array}$ & RSD (\%) \\
\hline Levocetirizine & 5 & $99.72 \pm 0.97$ & 0.98 \\
\hline Montelukast sodium & 10 & $100.19 \pm 1.06$ & 1.06 \\
\hline
\end{tabular}

(b) By HPLC

\begin{tabular}{|c|c|c|c|}
\hline \multirow[b]{2}{*}{ Drugs } & \multirow{2}{*}{$\begin{array}{l}\text { Label claim } \\
\text { mg tablet }^{-1}\end{array}$} & \multicolumn{2}{|c|}{ For HPLC $(n=6)$} \\
\hline & & $\begin{array}{l}\text { Drug content } \\
(\%) \pm \text { SD }\end{array}$ & RSD (\%) \\
\hline Levocetirizine & 5 & $99.76 \pm 0.55$ & 0.56 \\
\hline Montelukast sodium & 10 & $100.15 \pm 0.71$ & 0.71 \\
\hline
\end{tabular}

Table 5: Analysis of a marketed formulation (Assay)

Robustness: The standard deviation of the peak areas was calculated for each parameter and the RSD was found to be less than $2 \%$ for HPTLC. For HPLC, robustness of the method was studied by deliberately varying parameters like flow rate $\left( \pm 0.1 \mathrm{~mL} \mathrm{~min}{ }^{-1}\right)$ and mobile phase composition $( \pm 1 \mathrm{~mL})$.The low values of the RSD \%, as shown in Table 3 . indicated the robustness of the two proposed methods.

Specificity: The specificity of both methods was noticed by the complete separation of levocetirizine dihydrochloride and montelukast sodium peaks in the presence of tablet excipients. The peak purity of levocetirizine dihydrochlorideand Montelukast sodium was assessed by comparing their respective spectra at the peak start, apex and peak end positions of the spot i.e., $r(S, M)=0.9979$ and $r(M, E)=0.9986$. A good correlation $\left(r^{2}=0.9981\right)$ was also obtained between the standard and sample spectra of levocetirizine dihydrochloride and Montelukast sodium, respectively. For HPLC, no interference was observed due to any unknown excipients of tablet dosage forms at the retention times of levocetirizine dihydrochloride and montelukast sodium. The peaks obtained were sharp and had clear baseline separation for both the methods.

Accuracy: As shown from the data in Table 4, satisfactory recoveries \% with small relative standard deviations (RSD\%) were obtained at various added concentrations for both the methods. The results indicate that the methods are highly accurate for simultaneous determination of the two drugs.

Analysis of a marketed formulation (Assay): Using the proposed chromatographic methods, assays of levocetirizine dihydrochloride and montelukast sodium in their tablets were carried out. Satisfactory results were obtained for both drugs in a good agreement with the label claims thereby suggesting suitability of the method (Figure 3 and Figure 4$)$. The recovery $\% \pm$ RSD $\%$ of six replicate determinations were $99.72 \pm 0.98$ (levocetirizine), $100.19 \pm 1.06$ (montelukast sodium) for HPTLC and $99.76 \pm 0.56$ (levocetirizine), $100.15 \pm 0.71$ (montelukast sodium) for HPLC (Table 5).

\section{Conclusion}

The proposed HPTLC and HPLC methods provide simple, accurate and reproducible methods of quantitative analysis for simultaneous determination of levocetirizine dihydrochloride and montelukast sodium in bulk and in pharmaceutical formulation. Both methods were validated as per ICH guidelines. The methods are specific and there is no interference from any of the sample components. It was concluded that the developed method offered several advantages such as rapid, cost effective, simple mobile phase and sample preparation steps, improved sensitivity and comparative short run time made it specific, reliable and easily reproducible in any quality control set-up providing all the parameters are followed accurately for its intended use.

\section{Acknowledgments}

The authors would like to thank, Unichem laboratories Ltd, Bardez Goa, India and Lupin Ltd, Pune, India for the gift samples and Poona College of Pharmacy Bharati Vidyapeeth University for providing facilities and encouragement for carrying out this study.

\section{References}

1. http://en.wikipedia.org/wiki/Levocetirizine (assessed on March 14, 2009)

2. Day JH, Ellis AK, Rafeiro E (2004) Levocetirizine: A new selective $\mathrm{H} 1$ receptor antagonist for use in allergic disorders. Drugs Today 40: 415-421.

3. http://en.wikipedia.org/wiki/Montelukast_sodium (assessed on March 14, 2009)

4. Lipkowitz MA, Navarra T (2001) The Encyclopedia of Allergies. (2nd ed.). New York: Facts on File.

5. Claesson HE, Dahlén SE (1999) Asthma and leukotrienes: antileukotrienes as novel anti-asthmatic drugs. J Inter Med 245: 205-227.

6. Valacer DJ (1999) New treatments for asthma: the role of leukotriene modifier agents. J Natl Med Assoc 91: 26S-39S.

7. Van Hoecke H, Vandenbulcke L, Van Cauwenberge P (2007) Histamine and leukotriene receptor antagonism in the treatment of allergic rhinitis: an update. Drugs 67: 2717-2726.

8. Ciebiada M, Górska-Ciebiada M, DuBuske LM, Górski P (2006) Montelukas with desloratadine or levocetirizine for the treatment of persistent allergic rhinitis. Ann Allergy Asthma Immunol 97: 664-671.

9. Morita MR, Berton D, Boldin R, Barros FAP, Meurer EC, et al. (2008) Determination of levocetirizine in human plasma by liquid chromatographyelectrospray tandem mass spectrometry: Application to a bioequivalence study. J Chromatogr B Analyt Technol Biomed Life Sci 862: 132-139.

10. Arayne MS, Sultana N, Nawaz M (2008) Simultaneous quantitation of cefpirome and cetirizine or levocetirizine in pharmaceutical formulations and human plasma by RP-HPLC. J Anal Chem 63: 881-887.

11. Selvan PS, Gopinath R, Saravanan VS, Gopal N (2006) Simultaneous Estimation of Levocetirizine, Ambroxol, Phenylpropanolamine and Paracetamo in Combined Dosage Forms by RP-HPLC Method. Asian J Chem 18: 2591 2596.

12. Birajdar AS, Meyyanathan SN, Raja RB, Krishanaveni N, Suresh B (2008) Simultaneous analysis of ambroxol $\mathrm{HCl}$ with cetirizine $\mathrm{HCl}$ and of ambroxol $\mathrm{HC}$ with levo-cetirizine dihydrochloride in solid dosage forms by RP-HPLC. Acta Chromatographica 20: 411-421.

13. Alsarra IA (2004) Development of a stability-indicating HPLC method for the determination of montelukast in tablets and human plasma and its applications to pharmacokinetic and stability studies. Saudi Pharm J 12: 136-143.

14. Sane RT, Menezes A, Mote M, Moghe A Gundi G (2004) HPTLC determination of montelukast sodium in bulk drugs and pharmaceutical preparations. J Planar Chromatogr 17: 75-78.

15. Radhakrishna T, Narasaraju A, Ramakrishna M, Satyanarayana A (2003) Simultaneous determination of montelukast and loratadine by HPLC and derivative spectrophotometric methods. J Pharm Biomed Anal 31: 359-368.

16. Ashokkumar S, Senthil Raja M, Perumal P (2009) RP-HPLC Method Development and Validation for Simultaneous Estimation of Montelukast Sodium and levocetirizine Dihydrochloride. International journal of pharmaceutical research 1: 8-12.

17. Smita Sharmaa MC, Sharma DV, Kohlib AD, Sharma C (2010) Development and validation of tlc-densitometry method for simultaneous quantification of montelukast sodium and levocetirizine dihydrochloride pharmaceutical solid dosage form. Der Pharmacia Lettre 2: 489-494.

18. International Conference on Harmonization (2005) Q2 (R1) Validation of analytical procedures: text and methodology. International Conference on Harmonization, IFPMA, Geneva.

19. Snyder LR, Kirland JJ Glajch JL (1997) In: Practical HPLC method development 2nd edn. USA Wiley. 